\title{
The Effect of Socialization Group Activity Therapy on the Communication Ability of Patients Withdrawing at the Psychiatric Hospitals of West Nusa Tenggara Province
}

\author{
Mursaka $^{1}$, Menap $^{2}$, Sismulyanto ${ }^{2}$, Yahya Ulumuddin ${ }^{1}$, Nova Budiharjo ${ }^{1}$, OvieLestya Nurdiana ${ }^{1}$ \\ ${ }^{1}$ Postgraduate Student, ${ }^{2}$ Graduate School, Public Health Department, Universitas Qomarul Huda \\ BadaruddinBagu, West Nusa Tenggara, Indonesia
}

\begin{abstract}
Schizophrenic mental disorders often occur with social withdrawal disorders, followed by symptoms of disturbed sleep patterns, anger, ineffective coping, changes in thought processes. Socialization Group Activity Therapy is a therapeutic modality given to patients withdrawing to improve their ability to communicate well verbal and non-verbal. This study aimed to determine the effect of Socialization Group Activity Therapy on communication skills in withdrawn patients, with a one group pre-test-post-test control design research design which is one type of quasi-experimental method. Samples were taken based on the quota with a total sample of 10 control groups and 10 TAKS treatment groups. Collecting data in this study by observation refers to the components of the verbal communication assessment. The test was carried out using the Wilcoxon non-parametric statistical method with the set error level $\alpha=0.05$. The results of Wilcoxon gave a $Z$ value count $=-2.209 p$-value $=0.027$ for the control group and a $Z$ value $=-2.499 p$-value $=0.012<0.05$ for the SGAT treatment group. These two results suggest that statistically, the intervention has a significant effect on both the control group and the treatment group. From the results of the study, it can be concluded that there is a significant effect on the control group intervention with an average communication ability is sufficient, and there is a significant effect on the intervention group treatment with good communication skills on average. To increase human resources, especially in nursing, about SGAT, it is necessary to hold training on Socialization Group Activity Therapy.
\end{abstract}

Keywords: Group activity therapy, Communication, Clients, Withdrawal.

\section{Introduction}

Mental health problems have become a global concern because they are a major problem abroad. Even mental health has become a major issue and has become a resolution in the world health session, in Geneva, 2001, which all WHO member countries need to follow up because if not, it will create a burden for each country.

\section{Corresponding Author: \\ Mursaka \\ Postgraduate student, Universitas Qomarul Huda \\ BadaruddinBagu, H. Badaruddin-Bagu Street, Central \\ Lombok, Pringgarata, West Nusa Tenggara, Indonesia \\ Email: muhammadsaka710@gmail.com \\ Phone number: +62853-3893-6239}

Eleven percent $(11 \%)$ of the world's burden are mental and neurological disorders. Until 2020, it is anticipated that this burden will increase to $14.6 \%$.Mental health problems will become "the global burden of disease" (Michard \& Chaterina, 1999). This is a challenge for the "Public Health Policy" which traditionally pays more attention to infectious diseases. The standard measurement for global health needs has traditionally been the death rate from the disease. This causes mental disorders as if it is not a problem. With the existence of a new indicator, namely DALY (Disability Adjusted Life Year), it is known that mental disorders are a major health problem internationally ${ }^{(1)}$.

Very fast socio-economic changes and uncertain political situations lead to higher unemployment, poverty, and crime rates, this situation can increase 
the incidence of crises and mental disorders in human life. Psychosis is simply a mental disorder with a loss of sense of reality. This is known by the presence of disturbances in feelings (affect and emotions), thought processes, psychomotor and volition, in such a way that these things are not following reality. Schizophrenia is a form of psychosis that has often been found everywhere since time immemorial ${ }^{(1,2)}$.

The incidence and morbidity of schizophrenia mental disorders in the community is around 0.2 $0.8 \%$. If the total population of Indonesia based on the results of the 2010 census was $237,556,363$ people, then the total population of Indonesia suffering from schizophrenia would be 4,751,127 people. Schizophrenic mental disorders, frequent disorders of social relations withdrawal, followed by symptoms of disturbed sleep patterns, anger, ineffective coping, changes in thought processes. Changes in self-concept and spiritual distress $^{(2)}$.

Patient withdraws often symptoms of decreased verbal and non-verbal communication even to none, apathy (disregarding the surrounding environment), being alone (separating from others), decreased activity (not excited), disappointed, feeling useless, and avoiding interaction with other people. Patients with withdrawal need holistic and comprehensive handling and need to be equipped with the ability to communicate with other people in the group.Modality therapy is the main therapy in mental nursing. This therapy is given to change the patient's behavior from maladaptive behavior to adaptive behavior. Socialization Group Activity Therapy is a therapeutic modality given to patients withdrawing to improve their ability to communicate both verbally and non-verbally (patients are trained to be able to introduce themselves, be able to get acquainted with group members, be able to converse with group members, be able to convey and discussing conversational topics, being able to convey and discuss personal problems to others, being able to convey opinions), so that after returning from the Psychiatric hospitals, patients can interact and be accepted in the family environment and society in general, thereby reducing the frequency of recurrence ${ }^{(3)}$. The purpose of this study was to determine the effect of Socialization Group Activity Therapy on the communication skills of withdrawn patients at the Psychiatric hospitals of West Nusa Tenggara Province.

\section{Method}

The design of this study was to use one group pretest-post test control design. Subjects in this study were 20 patients in five inpatient rooms of the Psychiatric hospitalsof West Nusa Tenggara Province. The independent variable in this study was Socialization Group Activity Therapy. The dependent variable in this study is communication skills. The instrument used in the form of observation (checklist) refers to the verbal communication assessment component. Data analysis using Wilcoxon.

\section{Result}

\section{Univariate Analysis}

Table 1 Distribution of control group respondents

\begin{tabular}{|c|c|c|c|}
\hline No & Age & Frequency & Percentage (\%) \\
\hline 1 & $21-25$ & 4 & $40 \%$ \\
\hline 2 & $26-30$ & 3 & $30 \%$ \\
\hline 3 & $31-35$ & 3 & $30 \%$ \\
\hline No & Education & Frequency & Percentage (\%) \\
\hline 1 & Elementary School & 3 & $30 \%$ \\
\hline 2 & Junior High School & 4 & $40 \%$ \\
\hline 3 & Senior High School & 3 & $30 \%$ \\
\hline \multicolumn{2}{|r|}{ Total } & 10 & $100 \%$ \\
\hline
\end{tabular}


Cont... Table 1 Distribution of control group respondents

\begin{tabular}{|c|c|c|c|}
\hline No & Gender & Frequency & Percentage (\%) \\
\hline 1 & Male & 7 & $70 \%$ \\
\hline 2 & Female & 3 & $30 \%$ \\
\hline \multicolumn{2}{|c|}{ Total } & 10 & $100 \%$ \\
\hline No & Pre-test Communication Skills & Frequency & Percentage (\%) \\
\hline 1 & Good & 0 & $100 \%$ \\
\hline 2 & Enough & 10 & $0 \%$ \\
\hline 3 & Less & 0 & $100 \%$ \\
\hline \multicolumn{2}{|c|}{ Total } & 10 & Percentage (\%) \\
\hline No & Post-test communication skills & Frequency & $0 \%$ \\
\hline 1 & Good & 0 & $100 \%$ \\
\hline 2 & Enough & 10 & $0 \%$ \\
\hline 3 & Less & 0 & $100 \%$ \\
\hline
\end{tabular}

Based on table 1 shows that most of the respondents are in the 21-25 year age group, namely 4 respondents (40\%). Most of the respondents are at the junior high school level, namely 4 respondents (40\%). Most of the respondents were male, namely 7 respondents $(70 \%)$. All respondents have sufficient communication skills $(100 \%)$ before and after in the control group

Table 2 Distribution of respondents in the treatment group

\begin{tabular}{|c|c|c|c|}
\hline No & Age & Frequency & Percentage (\%) \\
\hline 1 & $21-25$ & 2 & $20 \%$ \\
\hline 2 & $26-30$ & 2 & $60 \%$ \\
\hline 3 & $31-35$ & 6 & $100 \%$ \\
\hline No & Total & 10 & Percentage (\%) \\
\hline 1 & Education & Frequency & $50 \%$ \\
\hline 2 & Elementary School & 5 & $30 \%$ \\
\hline
\end{tabular}


Cont... Table 2 Distribution of respondents in the treatment group

\begin{tabular}{|c|c|c|c|}
\hline 3 & Senior High School & 2 & $20 \%$ \\
\hline \multicolumn{2}{|r|}{ Total } & 10 & 10 \\
\hline No & Gender & Frequency & Percentage (\%) \\
\hline 1 & Male & 7 & $70 \%$ \\
\hline 2 & Female & 3 & $30 \%$ \\
\hline \multicolumn{2}{|r|}{ Total } & 10 & $100 \%$ \\
\hline No & Pre-Test communication skills & Frequency & Percentage (\%) \\
\hline 1 & Good & 0 & $0 \%$ \\
\hline 2 & Enough & 10 & $100 \%$ \\
\hline 3 & Less & 0 & $0 \%$ \\
\hline \multicolumn{2}{|r|}{ Total } & 10 & $100 \%$ \\
\hline No & Post-Test communication skills & Frequency & Percentage (\%) \\
\hline 1 & Good & 7 & $70 \%$ \\
\hline 2 & Enough & 3 & $30 \%$ \\
\hline 3 & Less & 0 & $0 \%$ \\
\hline \multicolumn{2}{|r|}{ Total } & 10 & $100 \%$ \\
\hline
\end{tabular}

Based on table 2, shows that the majority of respondents are in the 31-35 year age group, namely 6 respondents $(60 \%)$. Most of the respondents are at the elementary education level, namely 5 respondents $(50 \%)$. Most of the respondents were male, namely 7 respondents $(70 \%)$. All respondents have sufficient communication skills, namely 10 respondents $(100 \%)$ before treatment. Most of the respondents have good communication skills, namely 7 respondents $(70 \%)$ and enough 3 respondents $(30 \%)$ after treatment.

\section{Bivariate Analysis}

Analysis of pre-test and post-test using nonparametric methods with the Wilcoxon sign rank test on SPSS for Windows version 15 with a P-value $\leq$ 0.05 or $95 \%$ confidence level. If the probability of error ( $\rho$-value) is less than $\alpha$, then the test results are in the rejection area $\mathrm{H}_{o}$ so that $\mathrm{H}_{\mathrm{a}}$ is used as a conclusion, on the other hand, if $\rho$-value is greater than $\alpha$, then $H_{o}$ is used as a conclusion. Because in this study the p-value 
results are smaller than the error level $(\alpha)$, the hypothesis used is that the null hypothesis $(\mathrm{H})$ is rejected, so it can be concluded that there is an effect of the intervention on communication skills in the control group. The calculation results are as follows; The test results are in the form of $\mathrm{Z}$ count $=-2.295$ for the control group with $\mathrm{p}$-value $=0.022$ because the $\mathrm{p}$-value $<0.05$ so it is in the rejection area $\mathrm{H}(\mathrm{p}$-value $<\alpha)$. As a result of the rejection of $\mathrm{H}$, it can be concluded that communication skills in the post-test control group have a significant effect on improving communication in patients who withdraw. In the treatment group, the p-value results are smaller than the error level $(\alpha)$, then the hypothesis used is that the null hypothesis $(\mathrm{H})$ is rejected, so it can be concluded that there is an effect of the intervention on communication skills in the treatment group. The results of the calculation of $Z=-2,501^{\text {a }}$ for the TAKS treatment group with $p$-value $=0.012<0.05$ so that in the rejection area $\mathrm{H}_{0}(\mathrm{p}$-value $<\alpha)$ it can be concluded that TAKS in the treatment group has a significant effect on improving communication in patients who withdraw.

\section{Discussion}

The results of research conducted from 24 October 2011 to 6 November 2011 conducted at the Psychiatric hospitalsof NTB Province on the effect of socialization group activity therapy on communication skills in withdrawing patients with a total of 20 respondents. In this study, the respondents were divided into two groups consisting of one group of 10 people who were given TAKS treatment and one group of 10 people who were not given SGAT treatment (control group). In the TAKS treatment group, there were seven sessions of Socialization Group Activity Therapy (SGAT). Researchers made observations using the observation guidelines before the SGAT was carried out and after the SGAT was carried out in each session. Whereas in the control group the researchers conducted observations using observation guidelines before nursing care was given and after nursing care was provided for seven days. Based on the results of observations using observation guidelines in the control group and the SGAT treatment group, the following results were obtained:

From table 1 the pre-test control group and table 2 the post-test control group shows that all respondents have sufficient communication skills (100\%). According to Joseph ${ }^{(1)}$, at the beginning of the meeting between nurses and patients, new communication was established, here the nurse introduced herself to the client by greeting her in a friendly manner, both verbally and non-verbally, eye contact had to be maintained. It is necessary to have nurses present both physically and psychologically when communicating with patients. Presenting oneself physically, namely the attention given through the appearance of the body, is important in interpersonal communication in the form of words. The development of communication skills in this group can be formed because: 1) the ability of group members will influence other groups so that interaction and communication will occur between groups that are given treatment; 2) Strength is the ability of group members to influence other groups (Stuart \& Laraia); 3) Cohesivity is the strength of group members to achieve goals. To achieve this group cohesiveness, group members can encourage talking to one another ${ }^{(4)}$.

Storytelling can build a common identity in a group. This theory suggests that an individual's image of reality is guided or guided by a story that shows how an object should be believed, the story is created through interaction and symbolic communication in small groups, and is disseminated from one person to another. Respondents who have sufficient communication skills are 3 respondents (30\%). During the observation, the respondents did not use body language (eye contact, facial expressions, and posture $)^{(5)}$. This is consistent with what Nurhasanah $^{(6)}$ stated, 2010 that facial expressions are often used as an important basis in determining interpersonal opinions, eye contact is very important in interpersonal communication. People who maintain eye contact during a conversation are expressed as trustworthy.

\section{Conclusion}

The average post-test score of the control group is better than the pre-test, but the communication skills are still in the sufficient category. The average posttest score of the TAKS treatment group showed that the communication skills of the withdrawn patient were mostly in the good category. There was a significant effect on the improvement of communication skills in patients who withdrew after being given Socialization Group Activity Therapy in the TAKS treatment group, this was proven based on the Wilcoxon test p-value $0.012<\alpha 0.05$ and the control group with a p-value 0.022 $<\alpha 0.05$ indicates that there is a significant effect on improving patient communication skills by withdrawing.

Acknowledgment: I would like to thank the respondents who participated. 
Medico-legal Update, July-September 2021, Vol.21, No. 3

Conflict on Interest: There is no conflict of interest to be declared

\section{Source of Funding: None}

Ethical Clearance: The study was approved by the health research ethics commission

\section{Reference}

1. Yosep I. Mental Nursing [Internet]. Bandung: PT Refika Aditama; 2007 [cited 2021 Jan 19]. Available from: https://www.unpad.ac.id/buku/ keperawatan-jiwa/

2. MARAMIS WF. Psychiatric notes. Ed.2. Surabaya: Airlangga University Press; 2009.
3. Keliat BA. Mental Health Nursing Process [Internet]. 2nd ed. Jakarta: EGC; 2006 [cited 2021 Jan 19]. Available from: http://scholar.unand. ac.id/18689/9/DAFTAR PUSTAKA.pdf

4. Sutini T, Keliat BA, Gayatri D. The Effect of Group Self-Help Therapy on Family Coping with Mental Retarded Children. J Keperawatan Padjadjaran. 2014 Jan 1;2(2).

5. Copel LC. Mental Health and Psychiatry: Clinical guidelines [Internet]. Jakarta : EGC; 2015 [cited 2021 Jan 19].

6. Nurhasanah N. Communication Science in Nursing Context. Jakarta: TRANS INFO MEDIA; 2010. 